\title{
History of Human Thought Knowing God
}

\section{Syarifuddin}

Universitas Panca Budi, Medan, Indonesia

syarifuddin.aif60@gmail.com

\section{Abstract}

The aims of this study to find out the history of human thought knowing god. The result of this study The scientific content in the word of God which is owned by the belief of understanding the divinity of religious people, should be the responsibility of Muslim scientists to make it a scientific answer, to those who need it, including all children of the nation of different religions in life who are bound by the one God values. Currently, the interest of preaching and scientific seminars must be able to inspire, and change the mindset of people from not having their hijab open to God, to being able to open their veils to God, not to blaspheme and corner other people, especially those who are not of the same religion. Or in other words, it must be able to shift the soul of a believer into a pious person's soul instantly, with a strand of contemporary language, where in the language of da'wah. By having a good and correct divine science, it is clear that religion is nothing but composed of conceptually real laws like the universe which consists of nothing but the laws of physics, chemistry and biology. It's just that the dignity and dimensions of these religious laws are higher and are essential, absolute and if viewed philosophically it appears that this nature is very perfect. Divine philosophy teaches us how to utilize and apply both physical and spiritual aspects and how to conform to God's plan, and reveal the true purpose of life. In fact, as seen from a spiritual point of view, life has no division: life is one, as is constantly. There is no death, only constant change.

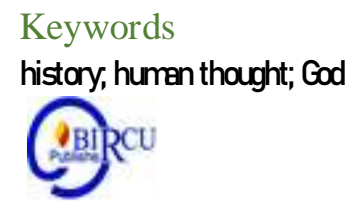

\section{Introduction}

Humans are given the opportunity to live only once in the world and will return to the afterlife. In this world given life and life, but there is a mortal enemy that is very powerful always accompanying humans, Demons and his descendants are devils, as his word surah al Israk [17] which means: [and say unto My servants, let them say the words that are better (true). In fact Demons caused a dispute between them. Indeed, Demons is the real enemy of humans]. (Kholil et al, 2020)

The understanding of divinity is a human acknowledgment of the existence of a creator, the ruler of nature, namely God Almighty / Allah SWT. Many countries whose community dominance consists of people with the Islamic religion of our country, the Republic of Indonesia has philosophically agreed to this divine understanding in the first principle of the state's foundation.

The Indonesian people have various beliefs, beliefs from different religious beliefs. ThereforeThe philosophy of divinity plays a very important role in explaining the notion of divinity so that differences in aqidah need to be known by every religious adherent so that it is 
clear where the common ground and the point of separation are, because the problem of one and only God which is the first principle in Pancasila demands that the Indonesian people embrace the teachings of divinity in each religion. Those who are in accordance with their choices as their basic rights and have high integrity accepting the differences in understanding and belief of every citizen. Togetherness in divinity as a nation but different in aqidah; an attitude of tolerance will become natural if citizens have knowledge in their religion, and can understand beliefs and can understand the beliefs and aqidah of other people.

History records that the most spectacular aspect of modernization is the shift of production techniques that rely on the use of animate sources, towards inanimate sources, as summarized in terms of the industrial revolution. In its development the process of changing production techniques is only one aspect of the modernization process. The process of modernization also hit Indonesia, where Indonesia is a country with a Muslim majority population, of course, to respond to the ideas of modernism in various forms in accordance with their educational and cultural background. However, of course the dynamics and power struggle between conservatism (which has always looked at Islam in the past) and progressivism (who want to reconstruct Islam for the future) is a latent agenda of Muslims throughout history. (Saburi et al, 2020)

Studying divine philosophy can be said as an endeavor, which discusses in search of things truth about God. Namely as a matter of "investigation of God who created the universe and all of its contents. It can also be said to be "an investigation into the divine world". This is so that people know about their God and to worship the Lord of the worlds. Studying divine philosophy is a human effort to understand, believe in God. So from this description obtained the belief in divine understanding. Or an attempt to find or explore the belief in understanding God in religion.

\section{Review of Literatures}

\subsection{School of Theism}

Theism is a school or understanding that recognizes God as a power that exceeds the power of everything in the creation of the world from nothing to being created and being willing to support his creatures. Through this creation, God and humans can establish a relationship. Harun Nasution in his book "philosophy of religion" explains that theism has understanding and differences, while the understanding of theism and deism argues that God is transcendent, outside nature, but close to nature. God is the cause for what is in this world. Everything rests on this cause. God is the basis of everything that exists and occurs in nature. This realm cannot exist and cannot exist without God. It is God who continues to directly control this universe.

Theism is also broadly defined as belief in existence God or god- goddess. In a layman's sense, or when compared todeism, terms like this are known as describing concepts deity classics that are often found in monotheism which is also called as classical theism found in religions polytheistic namely a belief in God without denying itthe existence of revelation derived from as contained in deism. The term theism was first used by a character Ralph Cudworth (1617-1688), which in philosophy divinity is used as the oppositeatheism.

Not all theisms have the same precepts, most of the theists believe that natural matter is real, while others claim that it is not. Most of them believe that God does not change, but some are influenced by pantheism, so they say that God changes in some ways. Some of these theisms argue that God created nature and always existed with it, while others believe that nature must have had a different beginning. 


\subsection{Deism}

In the teachings of God's deism, it is difficult for human reason to understand it. According to deism, God is far away outside of nature. God created nature, and after creating it God no longer cares for and cares for nature anymore. Nature operates according to the rules set during the creation process. But if we see it has something to do with the word of God in the holy book Q. S Assajadah / 32: 4, which means: Allah created the heavens and the earth and what is between them in six eras, then He resides above Arsy. There is no one for you apart from Him a helper and not (also) a shafa'at giver. Then are you not paying attention?

If we look further, the parable of deism is the logic of God as the one who made a very skilled clock, so that after the clock was finished, there was no need for the maker anymore. The clock runs according to a mechanism that is composed of what has become itself according to the elements of the clock, and this nature will not be damaged, nature cannot accept the divine dimension because it does not need God to manage it, because nature already has its own mechanism to maintain balance.

Deism (derived from the Latin "deus" meaning "God") is a philosophical belief that God exists as an uncaused First Cause, who is responsible for the creation of the universe, but then does not interfere with the world He created. . Equivalently, deism can also be defined as a view that places the existence of God as the cause of everything, and admits its perfection but has a very basic and fatal error, namely refusing to be in the form of miracles or some form of divine revelation or God's direct intervention in the universe.

\subsection{Agnostic}

Agnosticism is the belief or principle of agnostics regarding the existence of everything that is above, below, outside or behind material or physical phenomena or knowledge of God or metaphysics. The term Agnosticism comes from the Greek meaning meaningliterally someone who doesn't know. Although agnosticism is almost the same as atheism, agnosticism is notsynonym fromatheism.

Agnostic terminology is a person who has the view that the presence or absence of God cannot be known. Agnostic as opposed to gnostic, which means that God can be known as being or not. Atheists and theists have more implications for attitudes and actions. You are a theist if you believe God exists and all your actions are carried out guided by his orders, atheist if you do not think God exists and do not base your behavior on his commands.

From this emerge various modes of agnosticism, such as agnostic theists, namely those who worship God but admit that God cannot be known. and gnostic theists, namely those who worship God who believe that God's existence can be known. Then came the agnostic atheism, that is, those who do not believe in God and think that God exists or does not exist; and there were the gnostic atheists, those who did not worship God and thought that God simply did not exist.

Moving on from the various modes of agnosticism, we can see that there are actually many agnostic theists out there, namely those who do not believe that God exists or not but do worship just in case (this could also be a residue of fear that has been ingrained since childhood about hell and sins resulting from not worshiping the true God) or other reasons. For them, religion is sufficient as an identity for population interests, Just for identity. They prefer to be people who believe in God without religious practice. Yes, just believe in God 


\section{Discussion}

At the time of the Namrud kingdom as a ruler contained in the holy Koran, Namrud issued regulations that were very disturbing to humans in his time. However, he made a statement, if there is a baby born male then it must be killed. At the same time as this extraordinary statement Prophet Ibrahim was born. So that the birth of Prophet Ibrahim was not known, then the mother of Prophet Ibrahim AS exiled him to a forest in a cave that was impossible for people to know.

King Namrud has a very arrogant character, he doesn't want any other human being to take his position as ruler. With the making of these regulations the aim is that no man can replace and defeat him in power. However, because of the power of Allah the prophet Ibrahim was always protected by Allah SWT, until he grew up to be an adult under the protection of the palace of King Namrud himself. Prophet Ibrahim was a tough person who always survived various kinds of dangers. Until one day he can return to society.

When Prophet Ibrahim AS had returned to society, he felt that there was something unreasonable about the behavior of those who worship idols. Almost along the way, various houses and buildings there are always idols for the public to worship. Until he got home, the object was still found, it turned out that his uncle worked as a sculpture maker. He also asked himself questions and his curiosity was very great. So the big question arose in him who is God? Which is called God? So that arises in him the process of critical thinking. He always asked and enveloped the contents of his thoughts. Who really is God? Is it true that idols are God? The study of God in philosophy is commonly called philosophical theology.

This is not an investigation of Allah as an object, but the existence of the universe, that is, a created being, because Allah is viewed solely as the first cause, but not in Himself. Allah is not actually a matter of science, nor is it a theodies. So the understanding of Allah in religion must be separated by Allah in philosophy.

This opinion about studying God is rejected by some religious people, because it can cause confusion to think in believers. So a scientific way was adopted to differentiate from theology by juxtaposing divine philosophy with other philosophies (human philosophy, natural philosophy, etc.). So philosophers define it as an attempt made to better assess, and reflexively, the ultimate reality which is called God, the idea and image of God through our surroundings. The idea of God in religious people in general is usually explained in the character of God "Most High"

Humans who accept it for granted because of the hereditary teachings of their predecessors, humans are emphasized having to believe, without even asking. Man begins to ask why he exists? Why does nature exist? Then askGod related;who is Allah,substance, and why He exists. Anselm said, God is something greater than him that human beings can not think about, the Greatest, the Most Powerful, the Most Good and so on. According to Anselm, Christian teachings could be developed rationally without the help of other authorities (the Scriptures, revelation, the teachings of the Church Father).

Even it can explain the existence of God with an argument that even those who do not believe can accept. The existence of God begins with the human mind that accepts religious teachings for granted, but also asks who and why he exists, the natural world, and God himself can be accepted. All the answers will be answered by experts in a field called theology. theos and logos, the science of human relations and God's creation. The answers can vary greatly, depending on which religion and belief provides the answer. But at least there are some conclusions they provide in response to an approach in revealing the existence of God

God exists, and the existence of God can be proven by several expressions, namely those commonly known as empirical, rational, critical and intuitive approaches. Apart from the four 
approaches above, philosophy tries to prove human beliefs through various ways with the rationalism approach, positivism approach, spiritualism approach and metaphysics.

Prophet Ibrahim (as) was a prophet who advocated unity (monotheism) to God by using logic. For example, we can observe the quotations from the holy Koran. Prophet Ibrahim (as) was a person who used God's logic, meaning that in Prophet Abraham's view, God was the cause of all possible causes. God reaches out to the unseen and the real (empirical, materialist). Meanwhile, the opponents of the debate use their intellect which is limited to materialist logic.

The logic of God used by Prophet Abraham has no limitations, whereas materialist logic is limited by the dimensions of space and time. For this reason, Prophet Ibrahim (as) easily broke the followers of materialist logic to silence and amazement, or difficulty in keeping up with it.

However, even the Prophet Abraham (as) did not want to be trapped by God's logic that allows all that is impossible and will lead him to mystical teachings (myths). Prophet Ibrahim (as) tested God's logic in empirical truths. Because, God who is not limited by space and time, the truth must also be proven empirically.

Abraham's action of destroying the statues was seen and heard by them. Therefore, some of them said, 'We heard from some convincing sources, there was a young man who was desperate to denounce and destroy these idols, his name was Abraham. Hearing this public report, the Babilonia government took a firm stand. They said and ordered the law enforcers, 'then, take him, this reckless young man who is acting subversive to the city center by showing it to the crowd, so that they will see his face and witness the punishment that will be imposed on him.

Prophet Ibrahim was one of the prophets who received prayer after Prophet Muhammad. When we pray, surely when we do tahiyat the beginning and the end, besides saying two sentences of shahada and solawat to the Prophet, we also say solawat to Prophet Ibrahim. Then, have you ever thought why we also have to say solawat to Prophet Ibrahim.

This is because Abraham Ibrahim was the imam of the Prophets in logic. He was a prophet who succeeded in defending and liberating mankind from worshiping idols other than God and subverting mystical stories or myths about God. Prophet Ibrahim was a logician who succeeded in convincing religious followers to the degree of haqul sure. Prophet Ibrahim is the greatest prophet after the Prophet sallallaahu alaihi wa sallam.

\section{Conclusion}

The scientific content in the word of God which is owned by the belief of understanding the divinity of religious people, should be the responsibility of Muslim scientists to make it a scientific answer, to those who need it, including all children of the nation of different religions in life who are bound by the one God values. Currently, the interest of preaching and scientific seminars must be able to inspire, and change the mindset of people from not having their hijab open to God, to being able to open their veils to God, not to blaspheme and corner other people, especially those who are not of the same religion. Or in other words, it must be able to shift the soul of a believer into a pious person's soul instantly, with a strand of contemporary language, where in the language of da'wah.

By having a good and correct divine science, it is clear that religion is nothing but composed of conceptually real laws like the universe which consists of nothing but the laws of physics, chemistry and biology. It's just that the dignity and dimensions of these religious laws are higher and are essential, absolute and if viewed philosophically it appears that this nature is very perfect. Divine philosophy teaches us how to utilize and apply both physical and spiritual aspects and how to conform to God's plan, and reveal the true purpose of life. In fact, 
as seen from a spiritual point of view, life has no division: life is one, as is constantly. There is no death, only constant change.

The application of certain good and correct divine principles helps accelerate the evolution of a person to know who he is and the quantum leap to higher levels in mental intelligence and spiritual awareness.

\section{References}

Abdurrahman, Dudung. (1999). Metode Penelitian Sejarah. Jakarta: Logos Wacana Ilmu.

Asy Syeikh Abdul Qadir Al-Jailani, Sir Al Asrar. (1987). terjemahan oleh Zezen Zainal Abidin Zayadi Bazul Asyhab, Thinker's Laibrary Sdn. Bhd, Selanggor Dar Al Ihsan.

Armstrong, Karen. (2012). Sejarah Tuhan, Kisah 4000 Tahun Pencarian Tuhan Dalam AgamaAgama Manusia. Bandung: Mizan.

Azhar, Tauhid Nur. (2012). Mengenal Allah, Alam, Sains, Dan Teknologi, Mengurai TandaTanda Kebesaran Allah Di Alam Semesta.Solo: Tinta Medina.

Azyumardi Azra. (2006). Paradigma Baru Pendidikan Nasional Rekonstruksi dan Demokratisasi, Jakarta: Buku Kompas

Bagus, Lorens. (2005). Kamus Filsafat. Jakarta: Gramedia Pustaka Utama.

Bakhtiar, Amsal. (2015). Filsafat Agama, Wisata Pemikiran Dan Kepercayaan Manusia. Jakarta: Rajawali Pos.

Bahafdullah, Madjid Hasan. (2010). Dari Nabi Nuh Sampai Orang Hadhramaut Di Indonesia. Jakarta: Bania Publishing.

Baqi, Muhammad Fuad Abdul. (2005). Mutiara Hadits Shahih Bukhari Muslim.Surabaya: PT. Bina Ilmu.

Colin Rose dan Malcolm J. Nicholl. (2002). Accelerated Learning for The 21st Century (terj. Dedi Ahimsa). Bandung: Nuansa

Dilan. (2016). Ilmu Kalam Tematik, Klasik dan Kontemporer. Jakarta: PrenadaMedia.

Daniel Goleman.(1999). Working with Emotional Intelligence. (terj. Alex Tri Kancono Widodo), Jakarta: PT Gramedia.

Djamaan Nur. (2008). Tasawuf dan Tarekat Naqsyabandiyyah Pimpinan Saidi Syekh Kadirun Yahya. Malang: CV. Widya Karya, Cet. IV.

Ensiklopedi Islam, PT. Ichtiar Baru van Hoeve. Jakarta jilid 3, 1995.

Fakhruddin Ar-Raziy Imam. (1990). At Tafsir Al-Kabir aw Mafatih Al-Ghaib, jilid 21, Daar Al-Kutub Al-Ilmiyah, Baerut- Libanon.

Fu'ad Farid Ismail and Abdul Hamid Mutawali. (2017). Berfilsafat Itu Gampang Cara Mudah Belajar Filsafat Barat Dan Islam Untuk Pemuda. Yogyakarta: Ircisod.

Harahap, Syahrin. (2015). Islam dan Modernitas: Dari Teori Modernisasi Hingga Penegakan Kesalehan Modern. Jakarta: Kencana.

Herry Muhammad, et al. (2006). Tokoh-Tokoh Islam Yang Berpengaruh Abad 20. Jakarta: Gema Insani.

Iqbal, M. Syarif. (1991). Tentang Tuhan Dan Keindahan. Bandung: Mizan,

Jalaludin dan AbdullahIdi. (2014). Filsafat Pendidikan Manusia, Filsafat Dan Pendidikan. Jakarta: PT. Raja Grafindo Persada.

Kartanegara, Mulyadi. (2006). Menyelami Lubuk Tasawuf. Jakarta: Erlangga.

Kholil, S. et al. (2020). The Communication between God and Demons (An Analysis of Thematic Interpretation of Fi Zilal Al Quran). Budapest International Research and Critics Institute-Journal (BIRCI-Journal). P. 1227-1238.

Kuswanjono, Arqom. (2009). Integrasi Ilmu Dan Agama, Perspektif Filsafat Mulia Sadra. Yogyakarta: Badan Penerbit Filsafat UGM. 
Katimin, Mozaik. (2010). Pemikiran Islam, Dari Masa Klasik Sampai Masa Kontemporer. Medan: Cita Pustaka.

Kartanegara, Mulyadi. (2003). Minyibak Tirai Kejahilan, Pengantar Epistimologi Islam. Bandung: Mizan.

Mintaredja, Abbas Hamami. (2005). Filsafat Common Sence, George Edward MoorYogyakarta: Paradigma.

Nasution, Hasan Bakti. (2006). Hikmah Muta'aliyah, Pengantar Filsafat Islam Kontemporer.Jakarta: Cipta Pustaka Media.

Nawawi, Hadari. (1998). Metode Penelitian Bidang Sosial. Yogyakarta: Gajahmada University Press.

Palmer, Richard E. Hermeneutika. (2003). Teori Baru Mengenal Interpretasi.Yogyakarta: Pustaka Pelajar.

Sumantri, Jujun S. (1986). Ilmu Dalam Perspektif Moral, Sosial Dan Politik, Sebuah Dialog Tentang Dunia Keilmuan Dewasa Ini Jakarta: Gramedia.

Saefuddin, Didin. (2002). Pemikiran Moderen Dan Pemikiran Islam, Biografi Intelektual 17 Tokoh. Jakarta: Grasindo.

Shaleh, Dahlan. Asbabul Nuzul, Latar Belakang Histori Turunnya Ayat-Ayat Alquran. Bandung: Penerbit Diponegoro.

Scrutson, Roger. (2000). Sejarah Singkat Filsafat Moderen Dari Descrates Sampai Wittgenstein. Jakarta: PT. Pantja Simpati, 1986.

Thompson, Jhon B. (2005). Filsafat Bahasa Dan Hermeneutik, Untuk Penelitian Sosial. Surabaya: Penerbit Visi Humanika.

Thompson, John B. (2005).Filsafat Bahasa Dan Hermeneutik Untuk Penelitian Sosial. Surabaya: Visi Humanika.

Komarudin. (1979). Metode Penulisan Skripsi dan Tesis. Bandung: Remaja Rosdakaiya.

Saburi, A. et al. (2020). Contribution of NEO Modernism Thoughts on Islamic Thoughts in Indonesia. Budapest International Research and Critics Institute-Journal (BIRCIJournal). P. 1443-1452.

Scution Roger. (1986). Sejarah singkat Filsafat Moern dari Descartes sampai Wittgenstein. Jakarta: PT. Pantja Simpati, Cet I.

Suriasumantri, S. Jujun. (1996). Filsafat Ilmu Sebuah Pengantar Populer, Jakarta, Pustaka Sinar Harapan Purwanto, Ngalim. M. (2003). Ilmu Pendidikan Teoretis dan Praktis, Bandung, PT. Remaja Rosdakarya

Pidarta, Made. (1997). Landasan Kependidikan Stimulus Ilmu Pendidikan bercorak Indonesia, Jakarta, PT. Rineka Cipta.

Warson Munawwir Ahmad, Kamus Arab-Indonesia, Unit Penggadaan Buku Ilmiah Keagamaan Pondok Pesantren Al-Munawwir, Krapyak Yogyakarta

Yahya, Kadirun. (1985). Mutiara Alquran Dalam Capita Selekta, I, II, III, Tentang Agama, Metafisika Ilmu Eksakta. Medan: Lembaga Ilmiah Metafisika Tasawuf Islam (LIMTI).

Yunus Muhammad. (1989). Kamus Arab-Indonesia, PT. Hdakarya Agung, Jakarta. 